Marquette University

e-Publications@Marquette

College of Education Faculty Research and

Publications

Education, College of

6-1-2008

Caregiver Engagement in Religious Urban Elementary Schools

Martin Scanlan

Marquette University, martin.scanlan@marquette.edu

Accepted version. Marriage and Family Review, Vol. 43, No. 3-4 (2008): 308-337. DOI. (C) 2008

Taylor \& Francis (Haworth Press). Used with permission. 


\title{
Caregiver Engagement in Religious Urban Elementary Schools
}

\author{
Martin Scanlan \\ Department of Educational Policy and Leadership \\ School of Education, Marquette University \\ Milwaukee, WI
}

\begin{abstract}
This article examines how school leaders in a religious school serving traditionally marginalized students improve their school communities through constructing space for caregiver engagement. This study suggests how counter-narratives of critical care can inform social justice leadership in schools. The results, from a case study of a Catholic urban elementary school that uses innovative and effective strategies to engage caregivers, show that educational leaders create spaces for engaging caregivers by developing relationships with them and systematically reducing barriers to their participation in the school community. Analyzing these results through the critical care theory lens illuminates how these spaces value diverse forms of social and cultural capital are strengthened by alliances with nontraditional support structures. This research contributes to our evolving understanding of caregiver engagement by presenting a textured analysis of a case study as viewed through a critical care conceptual framework.
\end{abstract}

\section{Introduction}

A core principle of social justice education is reciprocal community relationships (Carlisle, Jackson, \& George, 2006). By this, Carlisle et al. (2006) refer to the school involving "families, local agencies, and community organizations in meeting its mission" ( $p$. 59). This article explores reciprocal community relationships by examining the role of school leaders in facilitating the engagement of caregivers in schools serving traditionally marginalized students, specifically students of color and students in poverty. Analyzing data Marriage and Family Review, Vol. 43, No. 3-4 (2008): pg. 308-337. DOI. This article is @ Taylor \& Francis (Routledge) and permission has been granted for this version to appear in e-Publications@Marquette. Taylor \& Francis (Routledge) does not grant permission for this article to be further copied/distributed or hosted elsewhere without the express permission from Taylor \& Francis (Routledge). 
from a case study of a Catholic urban elementary school that uses innovative and effective strategies to engage caregivers, this study suggests how counter-narratives of critical care can inform social justice leadership in schools.

\section{Significance of Problem}

Educational researchers have a long-standing interest in caregiver involvement (Coleman, 1991; Epstein, 1990, 1997; Hanafin \& Lynch, 2002; Henderson \& Mapp, 2002; Mandara, 2006; Rodgers \& Rose, 2001; Stolz et al., 2004; Ysseldyke \& Algozzine, 2006), and increasingly school districts and state agencies are instituting mechanisms to hold schools accountable to actively engage caregivers, to monitor the effectiveness of their strategies, and to respond to these assessments to continually improve in these endeavors (Christie, 2005). Rodgers and Rose (2001) report that although especially important in nonintact families, "Regardless of family structure, higher parental support and monitoring [are] predictive of academic success" (p. 58). Evidence abounds indicating that strong caregiver engagement is related to effective schools (Charles A. Dana Center, 1999; Fan \& Chen, 2001; Henderson \& Mapp, 2002; Osterman, 2000). Key to this is the expectations of caregivers. As Hoge, Smit, and Crist (1997) show, caregivers' high expectations about their children's achievement "has more impact than having interest in their grades or classes, being involved in school events, or having open communication with the children" (p. 34). This implies that schools promote student achievement when they engage caregivers around specific expectations of student success. Schools that successfully engage caregivers (i.e., parents and guardians) are more likely to be successful educational settings for students (Berger, 2000; Dwyer \& Hecht, 1992; Eccles \& Harold, 1996; Jeynes, 2005a,b).

Schools that engage diverse families are characterized by collaborative cultures respectful of differences (Henderson \& Mapp, 2002). Epstein (Epstein, 1986, 1990, 1993, 1997; Epstein \& Salinas, 2004), who has written extensively about school involvement with families and communities, enumerates multiple types of this engagement. Schools can support families in parenting their children

Marriage and Family Review, Vol. 43, No. 3-4 (2008): pg. 308-337. DOI. This article is @ Taylor \& Francis (Routledge) and permission has been granted for this version to appear in e-Publications@Marquette. Taylor \& Francis (Routledge) does not grant permission for this article to be further copied/distributed or hosted elsewhere without the express permission from Taylor \& Francis (Routledge). 
and in assisting their children's academic achievement through home supports. Schools are responsible for cultivating communication with families about the educational processes and outcomes. Schools facilitate family involvement in the schools through volunteering and decision-making mechanisms. Additionally, schools can help families access social service, educational, and enrichment resources in the community.

Yet all caregiver participation is not equal. As Perez Carreon, Drake, and Calabrese Barton state (2005), "[Caregiver] involvement is not a fixed event but a dynamic and everchanging practice that varies depending on the context in which it occurs, the resources parents and schools bring to their actions, and the students' particular needs" ( $p$. 465). Jeynes (2005b) finds that "some of the more subtle aspects of parental support and involvement, such as communication and parental family structure, may impact children's educational outcomes more than some of the more overt typical aspects of parental involvement that are more often regarded as important" (p. 114). Distinguishing meaningful caregiver participation entails critically reflecting on issues of privilege and marginalization (Lareau \& Shumar, 1996). Issues of power, authority, and control shape the involvement of caregivers in their children's education (Abrams \& Gibbs, 2002; Fine, 1993), which can negatively impact caregivers who are marginalized by poverty (Hanafin \& Lynch, 2002) and race (Lareau \& Horvat, 1999). Thus, to effectively involve caregivers in their children's education, schools must use multiple strategies of communicating with caregivers, define caregiver participation broadly, and avoid deficit orientations (Gutman \& McLoyd, 2000; Lopez, 2001; Lopez, Scribner, \& Mahitivanichcha, 2001; Valencia, 1997).

Participation of caregivers in schooling can be critiqued as lacking authenticity. Anderson (1998) maintains that discourses of participation are at times wielded as tools of public relations or mechanisms to control dissent, as "sites for collusion among dominant groups" (p. 574). To Anderson, "authentic" participation incorporates the micropolitical considerations of the local conditions that impact who participates and in which spheres as well as the macropolitical considerations of coherence between the means and ends of

Marriage and Family Review, Vol. 43, No. 3-4 (2008): pg. 308-337. DOI. This article is (C) Taylor \& Francis (Routledge) and permission has been granted for this version to appear in e-Publications@Marquette. Taylor \& Francis (Routledge) does not grant permission for this article to be further copied/distributed or hosted elsewhere without the express permission from Taylor \& Francis (Routledge). 
participation. Anderson cautions that "politics and power are embedded in a school's culture, resulting in a form of cultural politics that makes successful implementation of participatory structures more complex than current research indicates" (p. 592).

In short, the literature shows that engaging caregivers is an important and complex role for schools. The research reported in this article builds on and departs from this literature in two ways. First, it examines caregiver engagement under a novel conceptual framework of critical care theory (described below). Second, it uses this conceptual framework to analyze a school community frequently ignored in extant literature: a private school serving traditionally marginalized students. The engagement of caregivers is particularly salient in these schools. By their private nature, they are compelled to attract caregiver support to maintain enrollment and thereby remain viable school settings. By serving traditionally marginalized students, they are compelled to broaden their support beyond the caregivers to reduce dependence on tuition and to expand their resource base.

The question that guides this research is as follows: How do educational leaders create spaces for engaging caregivers in a religious school that primarily serves traditionally marginalized students? Though parochial in setting, the implications of this research are relevant to educators in both public and private settings committed to improving their school communities by more authentically engaging caregivers. The unit of analysis, educational leaders in a private school primarily serving students marginalized by racism and poverty, is well suited to this exploration. The profile of typical private schools that cater primarily to middle- or upper-class, tuition-paying caregivers (Alt \& Peter, 2002) does not fit this school, which serves students of low socioeconomic status and relies on diversified sources of funding. Moreover, the conceptual framework guiding this research recognizes race, racism, and White privilege as central factors. The participants in this research were predominantly White, middle-class women, whereas the students and families in their schools were people of color and of low socioeconomic status. The phenomenon of White educators effectively attracting support for private schools serving communities of color and communities of poverty speaks to how all school leaders

Marriage and Family Review, Vol. 43, No. 3-4 (2008): pg. 308-337. DOI. This article is @ Taylor \& Francis (Routledge) and permission has been granted for this version to appear in e-Publications@Marquette. Taylor \& Francis (Routledge) does not grant permission for this article to be further copied/distributed or hosted elsewhere without the express permission from Taylor \& Francis (Routledge). 
can effectively facilitate caregiver and community participation across racial and class lines.

\section{Conceptual Framework}

I approached this inquiry into how school leaders create space for engaging caregivers in private schools serving traditionally marginalized students through a conceptual framework of critical care theory. Critical care theory is emerging out of care theory, which emphasizes the role of schools and school leaders to foster nurturing, collaborative communities (Beck, 1994; Noddings, 2005b). According to care theory, educators must build trusting, respectful relationships with students. These relationships facilitate the empathy of the educators for the experiences of their students. Another dimension of care theory emphasizes collaboration. In a study of an inclusive Catholic high school, Bauer and Brown (2001) illustrate that collaboration "is a style for direct interaction between at least two equal parties engaged in shared decision making and working toward a common goal" (p. 16) and that collaboration can lead to "support, sharing, and relationship building among teachers, parents, and students" (p. 16). Finally, Noddings (2005a) points out that "An ethic of care is...future-oriented. Its work begins where an ethic of justice often ends" (p. 147).

Care theory becomes critical by placing issues of inclusion and marginalization at the center of inquiry. In their studies of Latino students' experiences of schooling, Rolon-Dow (2005) and Valenzuela (1999) bridge care theory with critical theories to better analyze sociocultural and racialized contexts. Valenzuela's critical analysis of how schools fail to effectively engage students across chasms of race and ethnicity, language, and class suggests that care theory needs to include a critical analysis of power, privilege, and marginalization. Rolon-Dow (2005) articulates an essential premise of critical care praxis: "to care for students of color in the United States, we must seek to understand the role that race and ethnicity has played in shaping and defining the sociocultural and political conditions of their communities" (p. 104). Rolon-Dow found "deficit-based, racialized caring narratives were often articulated when teachers used their own

Marriage and Family Review, Vol. 43, No. 3-4 (2008): pg. 308-337. DOI. This article is @ Taylor \& Francis (Routledge) and permission has been granted for this version to appear in e-Publications@Marquette. Taylor \& Francis (Routledge) does not grant permission for this article to be further copied/distributed or hosted elsewhere without the express permission from Taylor \& Francis (Routledge). 
experiences as well as the historical experiences of White immigrant groups as ideological foundations" (p. 104).

Beauboeuf-Lafontant (2002) contributes to articulating critical care theory in developing the notion of "womanism." According to Beauboeuf-Lafontant, womanism is "the cultural, historical, and political positionality of African-American women, a group that has experienced slavery, segregation, sexism, and classism for most of its history in the United States" (p. 72). Womanism is supported by three central tenets. The first tenet is a concern with oppression, defined as "an interlocking system, providing all people with varying degrees of penalty and privilege" (p. 72). The second tenet is social transformation, which involves "individual empowerment combined with collective action" (p. 72). Third, womanists are not solely concerned with their own interests but with social justice more broadly and accordingly "seek the liberation of all" (p. 72). BeauboeufLafontant characterizes womanists as demonstrating "political clarity" that allows them to "see racism and other systemic injustices as simultaneously social and educational problems. Consequently, they demonstrate a keen awareness of their power and responsibility as adults to contest the societal stereotypes imposed on children" ( $p$. 77).

Beauboeuf-Lafontant (2002) draws from womanists the implication that "caring need not be regarded simply as an interpersonal, dyadic, and apolitical interaction" (p. 83) but rather is a key tool to "communal engagement and political activism" (p. 83). In this analysis I apply these notions of womanism to analyze the actions of White educators. Though rooted in black feminism, BeauboeufLafontant notes that "not all womanists are African-American women. Because womanism is a politicized appropriation of some of the cultural values of black women, people choose whether or not to become womanists" (p. 85).

Thus my conceptual framework is best characterized as care theory with critical influences. Perez Carreon and colleagues (2005) argue that caregiver involvement "must be studied in connection to the spaces in which this involvement takes place, along with the

Marriage and Family Review, Vol. 43, No. 3-4 (2008): pg. 308-337. DOI. This article is (C) Taylor \& Francis (Routledge) and permission has been granted for this version to appear in e-Publications@Marquette. Taylor \& Francis (Routledge) does not grant permission for this article to be further copied/distributed or hosted elsewhere without the express permission from Taylor \& Francis (Routledge). 
physical, material, and organizational boundaries embedded in these spaces" (p. 468). My conceptual framework focuses attention on these "spaces" as sites where social and cultural capital are negotiated and ethics of care are established and practiced.

\section{Methods}

This study of caregiver engagement draws from data collected in a broader study. Using a multicase study design (Stake, 1985, 1995; Yin, 2003), I conducted a study of five Catholic elementary schools serving students in poverty (i.e., qualify for free or reduced price lunches), linguistic minorities (i.e., live in homes where a language other than English is spoken), people of color, and/or students with disabilities (Scanlan, 2006). Qualitative methods provided an avenue to examine the ways these schools understood and pursued inclusion of traditionally marginalized students (Carspecken, 1996; Lincoln \& Guba, 1985; Patton, 1990). During the 2004-2005 school year I collected data through interviewing, observing, and conducting archival research. My primary data were drawn from interviews with 75 research participants from administration, faculty, staff, and school boards. Seeking the perspectives of people who worked directly in the school or directly with the school, I conducted an initial semi-structured interview with each participant for 45 minutes to an hour. Through conducting a second interview with each of the administrators and written correspondences with select teachers, I gained additional data. I transcribed and coded these data, building a theoretical understanding of the way each school served the diversity of students (Maxwell, 1998; Strauss \& Corbin, 1990).

In addition to these interviews, I gathered observations though detailed descriptions, digital photographs, and audio-visual recordings of school events, along with archival documents related to each school's policies, procedures, and practices. I made between three and five site visits to each school, each lasting approximately 2 days. During these visits I made these observations and recorded them through field notes, digital photographs, and brief video recordings. Archival documents related to each school's enrollment trends, mission, policies and procedures of recruitment and retention, and

Marriage and Family Review, Vol. 43, No. 3-4 (2008): pg. 308-337. DOI. This article is (C) Taylor \& Francis (Routledge) and permission has been granted for this version to appear in e-Publications@Marquette. Taylor \& Francis (Routledge) does not grant permission for this article to be further copied/distributed or hosted elsewhere without the express permission from Taylor \& Francis (Routledge). 
funding and governance structures provided further data. My understanding of the inclusive practices in the schools was enhanced by observations of school artifacts such as classrooms, bulletin boards, and exhibits. In a similar manner to my interview data, I coded archival documents and observations through an interactive process of categorizing the data, contextualizing the relationships among these categories, and building theory (Maxwell, 1998; Strauss \& Corbin, 1990).

This article presents a reanalysis of select data gathered from this larger study, namely the strategies of caregiver engagement in one school, St. Josephine Academy (SJA) (all names are pseudonyms). SJA is a rich case for this analysis because the efforts to engage caregivers in this school were particularly well developed. For this article I reanalyzed data from SJA, including interviews of individuals in formal and informal leadership roles, observations, and archival documents, relating specifically to how this school community engaged caregivers.

\section{Results}

The data suggest that the leaders in SJA recognize that the onus is on them to engage stakeholders into the space and that failure to attract and maintain the support of caregivers will be costly. The term "leaders" is understood broadly as all educators in the school with roles of formal and informal authority. I present these data by first providing snapshots of the school, illustrating how its student body is composed across various dimensions of diversity. I then describe in depth how the school leaders create space for engaging caregivers.

\section{SJA: A Responsive, Caregiver-Oriented School}

Although SJA serves many students who traditionally could be considered as marginalized, the school is strikingly homogenous: The student body is composed of 260 African-American students in preschool to eighth grade ( $94 \%$ live in poverty). No students are linguistic minorities. Thus the school was not characterized by diversity.

Marriage and Family Review, Vol. 43, No. 3-4 (2008): pg. 308-337. DOI. This article is @ Taylor \& Francis (Routledge) and permission has been granted for this version to appear in e-Publications@Marquette. Taylor \& Francis (Routledge) does not grant permission for this article to be further copied/distributed or hosted elsewhere without the express permission from Taylor \& Francis (Routledge). 
NOT THE PUBLISHED VERSION; this is the author's final, peer-reviewed manuscript. The published version may be accessed by following the link in the citation at the bottom of the page.

SJA, as a Catholic school, has persisted against the odds. Ms. Mayes, an alumnus of the school who now works as an aide, explains: "There used to be 10 Catholic schools in [this] area-now there are 3." In this Midwestern metropolitan neighborhood, over $30 \%$ of the people in the neighborhood live in poverty. Abandoned and dilapidated buildings line the streets, and criminal activity is frequent. The school has tight security measures in place, including secured doors and parking and video monitoring of entrances. During one of my site visits, a neighborhood resident was shot less than a block from the school. Moreover, SJA has grown isolated from other Church-based supports, losing both its local parish and a community of religious sisters in the past two decades.

The school has significant mismatches in race and ethnicity and socioeconomic status between the research participants and the students. Serving students of color and students in poverty, SJA is mostly staffed by White women who are not living in poverty. Though the school managed to attract and retain select teachers for significant periods, each year it relies heavily on an influx of new, young, and relatively inexperienced teachers. Safety concerns force the principal to forbid staff members from staying late to work in school. In addition, the school is located in an area that made it difficult to find, squirreled away off main thoroughfares, surrounded by one-way streets and avenues. From her 22 years teaching in the middle school, Ms. Abrams describes SJA as "the best kept secret [in the neighborhood]."

This context helps explain the paramount challenges at SJA: maintaining a steady student enrollment and ensuring financial viability. The monthly tuition expense ( $\$ 260$ for one child, $\$ 374$ for two children) is the most significant barrier to attracting and retaining students in SJA. Many families receive tuition assistance in the form of tuition scholarships, provided through external fundraising efforts led by the school principal, Ms. Green. According to Ms. Wallace, secretary for 17 years, "Ms. Green does a very good job of keeping children here. A lot of people have stayed after talking to her and after her finding patrons and finding people to help with tuition-that keeps a lot

Marriage and Family Review, Vol. 43, No. 3-4 (2008): pg. 308-337. DOI. This article is (C) Taylor \& Francis (Routledge) and permission has been granted for this version to appear in e-Publications@Marquette. Taylor \& Francis (Routledge) does not grant permission for this article to be further copied/distributed or hosted elsewhere without the express permission from Taylor \& Francis (Routledge). 
of our families here." One teacher's comments reflect what many research participants expressed: "Usually, the reasons for [students] leaving will be financial."

In addition to serving many students who cannot afford to attend a school that charges tuition, SJA makes concerted efforts to serve students with disabilities. According to an audit by the Diocesan Office (the central organizing unit for Catholic schools, akin to a public school district), approximately 1 in 10 students in SJA has a disability. SJA does not label students with disabilities in the manner typical of public schools (such as with Individualized Educational Plans); the educators at SJA have "staffings" on students who are struggling. The principal, Ms. Green, reported that during the spring of 2004 the school was "selected as a site for inclusion by the diocese." The diocese assigned a "learning specialist [to] join [the staff] with a background in special ed. and speech." In addition, the staff at SJA has been focusing professional development on improving service delivery to all students. They have brought in a consultant from a local university to work with teachers 1 day a week on differentiating the curriculum and more effectively reaching students who are having challenges in class. Teachers rely on consultation with the principal, with peers, and with other professionals (i.e., school counselors) in the school when adapting to meet the needs of the students. One student in SJA has a significant mobility impairment. A retrofit of the building with an elevator and other accommodations has made the site accessible.

Finally, the mission of SJA advocates reaching out to children and families with an atmosphere of openness and welcome:

The Mission of SJA is to nurture the body, mind, and spirit of each child entrusted to our care. Our goal is to forge a partnership with our families so together we foster the spiritual, social, intellectual, emotional and physical development of our young people. We aim to provide for our students a caring but disciplined environment, which encourages the pursuit of excellence, enthusiasm for learning, pride of accomplishment, self-discipline, and consideration for others.

Marriage and Family Review, Vol. 43, No. 3-4 (2008): pg. 308-337. DOI. This article is (C) Taylor \& Francis (Routledge) and permission has been granted for this version to appear in e-Publications@Marquette. Taylor \& Francis (Routledge) does not grant permission for this article to be further copied/distributed or hosted elsewhere without the express permission from Taylor \& Francis (Routledge). 
NOT THE PUBLISHED VERSION; this is the author's final, peer-reviewed manuscript. The published version may be accessed by following the link in the citation at the bottom of the page.

Perhaps more importantly than the written version, the tacit mission in SJA emphasizes that all are welcome. In a response typical of her colleagues, Ms. Harris, who has taught at the school for two decades, described the goal of the school in these terms:

I think that the purpose that the principal has tried to set here is that we serve every child, in spite of whatever their needs are, in spite of the troubles they might have had. We want to be able to work with any child-no matter how low their educational abilities might be. We want to be able to serve everyoneanyone and everyone-any child.

This snapshot of SJA sets the stage for understanding how the educational leaders at SJA articulated their role in creating a school community that is extraordinarily responsive to caregivers. The educators work to cultivate a space that fosters supportive relationships with caregivers and reduces barriers to their participation. An overview of this snapshot is provided in Figure 1.

\section{Caregiver Engagement at SJA}

These findings show that educational leaders in SJA create spaces for engaging caregivers by developing deep relationships with their students and students' families. Ms. Wallace, the school secretary for the past two decades, interacts with families more than anyone. She describes the supportive culture of the school as stemming from "the hospitality and the caring" and "the attention that is given to the children." Elaborating, she connects this to how teachers forge deep relationships with the children and their families: "It's not just the kids, it's the family: getting involved with the family and the children." She explained:

The teacher may have 20 some odd children in the classroom but it just seems like that personal attention is geared towards that one student as far as from the time they walk in that door 'til the time that they walk home.... The teachers and the staff here are always so concerned and they know what goes on throughout the whole day of the child. It's not like the child comes in to the classroom, does the work, and that's it.

Marriage and Family Review, Vol. 43, No. 3-4 (2008): pg. 308-337. DOI. This article is (C) Taylor \& Francis (Routledge) and permission has been granted for this version to appear in e-Publications@Marquette. Taylor \& Francis (Routledge) does not grant permission for this article to be further copied/distributed or hosted elsewhere without the express permission from Taylor \& Francis (Routledge). 
NOT THE PUBLISHED VERSION; this is the author's final, peer-reviewed manuscript. The published version may be accessed by following the link in the citation at the bottom of the page.

These strong relationships are best exemplified by (1) the personal attention the principal models, (2) the strong teacher-family communication networks, and (3) the systems that reduce barriers to families.

\section{Personal Attention From the Principal}

A fundamental way SJA engages caregivers is through the personal attention of the principal. Ms. Green, the principal of SJA, lays the foundation for the strong school-caregiver relationship by conducting an entry interview with each new family.

Ms. Morgan, a teacher for the last 2 years in the primary grades, mentioned the importance of these entry interviews when describing how she would frequently consult with Ms. Green about concerns with particular students. She explained that in addition to paying attention to their grades by regularly reviewing student work, the principal brings a depth of knowledge about their families: "She knows their family history because she interviews every family-long interviews-15-20 minutes and learns their family history, their jobs, family background, relationships-and parents are just drawn to come in and talk to her.... She really tries to meet the needs of each family." A veteran teacher in the intermediate grades, Ms. Harris indicated that this entry interview process allows SJA to serve families whose children have struggled and failed in public schools:

When [Ms. Green] starts the interviews with students who might have been put out of public schools she'll talk with them about how they plan on making changes in our school, so they'll know that it's a loving, caring, safe environment. And that she always makes sure that if there was a problem that she'll hook up counseling with the child right away-a lot of time the counselor will be in the room right away with the child.

The power of this connection between the principal and the families in the school is illustrated in an anecdote from Ms. Wells, a neighborhood resident who has volunteered at the school for over a decade and now serves on the school board. She sent her child, who is now in high school, through SJA. Her story captures the way Ms.

Marriage and Family Review, Vol. 43, No. 3-4 (2008): pg. 308-337. DOI. This article is (C Taylor \& Francis (Routledge) and permission has been granted for this version to appear in e-Publications@Marquette. Taylor \& Francis (Routledge) does not grant permission for this article to be further copied/distributed or hosted elsewhere without the express permission from Taylor \& Francis (Routledge). 
Green in particular and this school community in general brings parents into a deeper relationship with the school. She went into Ms. Green's office one day to let her know that she would not be able to keep her daughter, who was in first grade at the time, in SJA. She was behind on payments and was not going to be able to sustain them. Instead of leaving the school with an unpaid bill, Ms. Wells went to settle her account. She recalls what happened:

I came to transfer my little girl. I'd lost my job... and Ms. Green asked if I could volunteer for her a little. At first I was reluctant, and then I said why not? I've been here ever since! My daughter's now a sophomore in HS-she's doing good.... Ms. Green tries really hard. You come in that door, and you sit in her office, and financial reasons, which I've experienced myself-for some reason-I don't know why...but you can't leave here! I'll see what I can do to help, but you can't leave here. I walked in this door to transfer my child and pay a balance, and I've been captured in here ever since!

Thus a mother who was on the brink of leaving this school community wound up becoming a dedicated volunteer, who continues to assist the school even after her daughter has graduated.

Ms. Coss, a board member and parent of an SJA alumnus, provides another perspective on this: "Ms. Green is concerned about not only how the child is doing at school but at home as well." She noted, "If the parent needs to do something-like attend a parenting class or something like that-we have that also." Asking a family to withdraw their child happens rarely. The infrequency is largely due to the tone set by the principal: "Ms. Green is very tolerant, and she tries to help us be tolerant too." Ms. Harris, a veteran teacher of the intermediate grades, attributes this to making the expectations clear when a child is entering the school:

It's kind of like making a commitment, especially when you're coming out of other schools where you've had a problem. It takes a commitment and taking responsibility for their part in whatever happened, and what is going to make a difference here-and they have to commit to making a difference when they come to our school. And that might mean pulling out a contract with the counselor or with Ms. Green.

Marriage and Family Review, Vol. 43, No. 3-4 (2008): pg. 308-337. DOI. This article is @ Taylor \& Francis (Routledge) and permission has been granted for this version to appear in e-Publications@Marquette. Taylor \& Francis (Routledge) does not grant permission for this article to be further copied/distributed or hosted elsewhere without the express permission from Taylor \& Francis (Routledge). 
The comments of Ms. Harris suggest asking uncooperative parents to leave is infrequently done precisely because the supportive relationships in the school are so strong. Successfully integrating students who come with a track record of having struggled at previous schools is tricky. Ms. Harris credits Ms. Green with setting the tone for this (tolerance) as well as the structure to facilitate it (e.g., getting family commitment, creating a contract with students).

Observations during site visits further supported these reports of research participants. Ms. Green spent considerable time with individual parents and families in both formal and informal meetings. She balanced this by making her presence ubiquitously felt among the student body, frequently interacting with students in the hall, speaking with them by name and discussing personal as well as academic matters. She is, in the words of Ms. Wallace, the secretary, "the glue to the school."

In summary, Ms. Green builds strong relationships with the students in the school and their families. As she put it, "You have to stay connected-the foundation of this school is to be connected." She intentionally brings parents into a deep relationship with the school from their initial encounter and maintains these relationships throughout. This personal attention from the principal is one way that educational leaders create spaces for engaging caregivers in SJA.

\section{Proactive, Positive, Focused Communication From Teachers}

A second way that educational leaders in SJA create spaces for engaging caregivers is by teachers developing strong bonds with the families. These bonds are built through initiating and sustaining contact that is both positive and focused on student growth and success.

The principal, Ms. Green, has worked hard to establish a culture of communication within the school. The teachers universally expressed this. Ms. Morgan, a new teacher, described this culture:

Marriage and Family Review, Vol. 43, No. 3-4 (2008): pg. 308-337. DOI. This article is (C) Taylor \& Francis (Routledge) and permission has been granted for this version to appear in e-Publications@Marquette. Taylor \& Francis (Routledge) does not grant permission for this article to be further copied/distributed or hosted elsewhere without the express permission from Taylor \& Francis (Routledge). 
We all communicate. It's just something we all do....It sounds cliché but it really is like family here. I don't know many places that are like this.... [Other schools] are like apartment buildings-you go in your classroom and you're there. This really is like a house-you can't get away from people. You can't get away from help and you can't get away from support. And I think that really makes a world of difference.

Ms. Sterling, a primary teacher for the past 4 years, described frequently calling home to report both negative and positive behavior. When asked how often she called her students' families, she replied: "Half the class a week....I guess it's easier for me to call them first. I'll just check in and say, '[W]ell, so and so is doing fine. Do you have any questions or concerns?"'

This communication is focused on student success. Ms. Morgan explained that this was non-negotiable: "Our parents would have our heads if they didn't have communication with us throughout a quarter before they got here for report cards! That's just what they're used to." Ms. Grady, working with the primary grades, emphasized that these relationships were connected to caring for the individual success of each child and recognizing them in the context of a family:

I think that there's a special kind of care that happens here and there's a belief that every student can succeed. And in the relationships that we've built with the parents. It's only a couple months into school and I've spoken to every one of my parents several times. You just do it-it's an expectation. It's there and you need to. In addition to four positive phone calls a week, there are many negative phone calls: there are many times I say we're trying to correct behavior-we're trying to work with your student on such and such, academically, behaviorally, that all needs to be communicated to the parents....And I think the parents appreciate that. We treat them like real people and people who are also involved with the execution. It's not just the teacher's efforts, it's not just the student's efforts-it's going to take all of us. And parent cooperation is crucial.

Strong, multifaceted communication and collaboration building relationships of mutual understanding and respect is an important dimension to the way the school creates a space of caregiver

Marriage and Family Review, Vol. 43, No. 3-4 (2008): pg. 308-337. DOI. This article is @ Taylor \& Francis (Routledge) and permission has been granted for this version to appear in e-Publications@Marquette. Taylor \& Francis (Routledge) does not grant permission for this article to be further copied/distributed or hosted elsewhere without the express permission from Taylor \& Francis (Routledge). 
NOT THE PUBLISHED VERSION; this is the author's final, peer-reviewed manuscript. The published version may be accessed by following the link in the citation at the bottom of the page.

engagement. Along with requiring that all teachers make positive contacts to caregivers weekly, Ms. Green requires that they focus conferences with the parents primarily on academic, not behavioral, matters. Grade conferences are three-way (Freeman, 1975; McKenzie \& Scheurich, 2004), involving teachers, students, and caregivers together.

Ms. Grady talked about how the frequent communication with parents about seemingly minor details was a way in which the school affirmed the dignity of all the members. She pointed out that although this was sometimes burdensome on the teachers, it was beneficial to them as well:

I think [our Catholic identity] is shown in a more real way in the phone calls. How many teachers actually take the time...to call in the week and say, "I really like the way so and so wrote his name down on the paper"? That attention speaks volumes.

This is a practical example of how the school attempts to meet the goal mentioned in the school's mission "to forge a partnership with our families."

Ms. Morgan explained the strength of these relationships with families as a counterbalance to the weak formal supports for students with disabilities that the school is able to offer. "We're working on inclusion. We have a grant that is teaching the teachers how to be inclusive of all children," she explained, but when asked if the school was able to meet the needs of all the children, she candidly acknowledged the school's limitations: "To be honest, a lot of times they're not totally met here. But the difference with this school we have constant communication with the parents."

An additional effect of these strong relationships is the influence on teacher dispositions. Another teacher, Ms. Sterling, has taught in the school for 4 years. She reflects that her perspective toward caregivers has shifted over these years:

I think parents play a more important role in my teaching now than they did my first year. I think that's gained through a little more respect-probably me respecting them more, and them respecting me more for being here.... Obviously there's [sic]

Marriage and Family Review, Vol. 43, No. 3-4 (2008): pg. 308-337. DOI. This article is @ Taylor \& Francis (Routledge) and permission has been granted for this version to appear in e-Publications@Marquette. Taylor \& Francis (Routledge) does not grant permission for this article to be further copied/distributed or hosted elsewhere without the express permission from Taylor \& Francis (Routledge). 
always exceptions-there are always difficult parents and that's going to happen. But my relationship with the parents has been much different and even the past two years than my first yearI didn't see them as supportive. I didn't see them! If they came with concerns I almost saw it as them complaining. Now whenever I do get parents who are like, "Why did my kid get this mark?" or "How come they don't know that?" I always say immediately, "Please come in so we can talk about it!" Because they're concerned and they're not complaining. I guess it's that I see engaged and interested parents as ones who will come talk to you and will come ask questions, whereas I've realized that someone that doesn't say anything and is never around well, that's not really doing any good for their kids.

The strong relationships between teachers and caregivers contribute to a caring culture in SJA. The culture of the school reflected this care for students in many ways, including artifacts of student work lining in hallways, the atmosphere of exuberance at student assemblies, and a controlled but lively tenor in the cafeteria at breakfast and lunch. These relationships are not left to the independent dispositions of individual teachers but rather are encouraged, fostered, and compelled from multiple directions. The culture of the school has created this expectation of proactive, positive, focused communication. This is a second significant way that SJA creates an engaging space for caregivers.

\section{Systems to Reduce Barriers to Families}

A final way SJA creates this space by fostering relationships with caregivers is through systematically reducing barriers to caregiver participation. SJA depends on attracting and retaining families in the school and thus has a strong incentive to make these connections. In a comment reflective of many participants, Ms. Grady describes this pressure to serve families well:

There's a huge effort in the primary grades to have as many students as possible in the student body [whose] experience is positive [so that] by the time they get on to 6th and 7th grade we'll still have a good size graduating class. I feel a huge responsibility in light of that, because I think a lot of these students could easily turn to public schools or to another school, and they don't. Their families continue to come back.

Marriage and Family Review, Vol. 43, No. 3-4 (2008): pg. 308-337. DOI. This article is (C) Taylor \& Francis (Routledge) and permission has been granted for this version to appear in e-Publications@Marquette. Taylor \& Francis (Routledge) does not grant permission for this article to be further copied/distributed or hosted elsewhere without the express permission from Taylor \& Francis (Routledge). 
One key barrier the school is constantly focused on reducing is the financial burden of the tuition. SJA offers to all families a tuition subsidy of $\$ 600$ if they participate in the school's Stewardship Program. Participating families (and virtually all families in SJA participate) are required to regularly attend some church (regardless of the denomination) and participate in school-based enrichment or service projects. Some of these projects include personal enrichment sessions, such as reading instruction workshops and parenting support sessions.

SJA also offers scholarships to families who could not otherwise afford the school's tuition. All Our Children is a local, independent, notfor-profit organization whose mission is to "provide support to the Catholic schools in the neediest areas of inner city and serves to help raise scholarship funds for students attending Catholic schools in the inner city." The average amount of annual support for scholarships during the last 6 years from All Our Children was just over $\$ 40,000$. The other funds they have provided have been primarily allocated to operating expenses or capital expenses. SJA also pursues tuition scholarships from other agencies and donors.

Also, SJA reduces the barrier of fear that caregivers have for their children's safety. Situated in a rough neighborhood, SJA strives to provide to caregivers a trusted haven for the children. Ms. Wells, a volunteer in the school for decades who sent her own children through the school, has a historical perspective on this: "It's a safe place here. A lot of children leave here...graduate, and go to high school-they come back [and]...bring their children here. They were safe-they felt safe." Ms. Mayes, an alumnus of the school who now works as an aide, spoke to this as well:

The parents, our parents know this: they drop their kids off sometime 6:30 in the morning and when we see them again it's 6:00 at night. And they don't say [to their children], "Have you had a snack? Have you done this or that?" They say [to us], "Thank you."

Marriage and Family Review, Vol. 43, No. 3-4 (2008): pg. 308-337. DOI. This article is (C) Taylor \& Francis (Routledge) and permission has been granted for this version to appear in e-Publications@Marquette. Taylor \& Francis (Routledge) does not grant permission for this article to be further copied/distributed or hosted elsewhere without the express permission from Taylor \& Francis (Routledge). 
NOT THE PUBLISHED VERSION; this is the author's final, peer-reviewed manuscript. The published version may be accessed by following the link in the citation at the bottom of the page.

In a community where violent acts are not uncommon, lack of safety is a significant barrier. The caregivers who send their children to SJA trust that their children are well cared for in a safe environment.

Finally, SJA attempts to mitigate many of the other barriers that many Catholic schools present by virtue of their private nature, such as excluding students with disabilities or learning problems or behavior problems. SJA systematically increases its capacity to serve students with diverse needs by drawing upon external agencies for support. For instance, the school collaborates with local nonprofit agencies to provide counseling services to students and families. Collegial relationships build a supportive culture in the school. Ms. Wellstone comes into SJA once a week to help teachers strategize methods for differentiating instruction within their classrooms. As a Black woman and a doctoral candidate in education at a local university, Ms. Wellstone brings an important perspective, racially and educationally. When considering what was working in this regard at SJA, she began with mentioning the leadership:

The success of a school lies in the leadership. I think a lot of that goes back to leadership. There's very strong leadership here. You have leadership that wants the best for the students and teachers and uses everything it does as a partnership. You don't find that at a lot of schools. You find a lot of schools with inhibitions or that rely on a lot of people within their school with inhibitions or with biases that they won't admit that they have. Therefore the attainment of their goal is not really met. On paper it looks good, but it's not really met. You don't have that here. You don't have people saying, "Oh those poor little black children, oh they don't know how to learn." No, you don't have that.

Ms. Wellstone then moved to capture the sense of strong expectations, openness to new ideas, and collaboration among the educators throughout SJA:

You have people [at SJA] that are like, "You can do this, you will do this." They might be struggling to find the best method to make it work, but then again they're not wed to just one method-they're committed to finding what is going to work. Bottom line is, what's going to work? The collaboration and the Marriage and Family Review, Vol. 43, No. 3-4 (2008): pg. 308-337. DOI. This article is (C) Taylor \& Francis (Routledge) and permission has been granted for this version to appear in e-Publications@Marquette. Taylor \& Francis (Routledge) does not grant permission for this article to be further copied/distributed or hosted elsewhere without the express permission from Taylor \& Francis (Routledge). 
willingness to work with people in general... if someone has a gift, and they're willing to share it, then you're welcome.

Ms. Wellstone's reflections are representative of an array of participants who spoke to the ways that the educators sought to meet the diverse learning needs of all students in the school community.

Thus by systematically working to reduce barriers to families, SJA illustrates a school community that takes seriously its responsibility to be accessible. Access to students with exceptionalities is one example of this. Barriers of fear and tuition are two other impediments that the school has established clear structures to address.

The focus of this inquiry was on how educational leaders in a religious school that primarily serves traditionally marginalized students create spaces for engaging caregivers. These data show that three ways this is accomplished at SJA are through the personal attention of the principal, the strong relationships of the teachers, and the systems to reduce barriers to caregivers. Analyses of these data show that SJA creates space to negotiate social and cultural capital and practice ethics of care.

\section{Discussion}

As described earlier, caregiver involvement is connected to the spaces in which it occurs (Perez Carreon et al., 2005). The critical care theory lens illuminates how these educational leaders create spaces for engaging caregivers and building community support. I present three dimensions to these spaces of engagement: These spaces (1) value diverse forms of social and cultural capital, (2) are strengthened by alliances with nontraditional supports, and (3) are limited. I conclude by suggesting that the caregiver engagement in SJA provides a counter-narrative to stock stories of how private schools serve traditionally marginalized students.

\section{Spaces Valuing Diverse Forms of Social and Cultural Capital}

Marriage and Family Review, Vol. 43, No. 3-4 (2008): pg. 308-337. DOI. This article is @ Taylor \& Francis (Routledge) and permission has been granted for this version to appear in e-Publications@Marquette. Taylor \& Francis (Routledge) does not grant permission for this article to be further copied/distributed or hosted elsewhere without the express permission from Taylor \& Francis (Routledge). 
Diverse forms of social and cultural capital are valued in the spaces created by the relationships and the reduction of barriers to the school. The findings suggest that the educators in SJA approach caregivers through an asset-oriented framework, working to build connections to them. The efforts of the educational leaders in SJA to create spaces that valued diverse forms of social and cultural capital can be interpreted as tactical and as value-laden. In a way, the schools were forced to create these spaces as a tactic to build their enrollments. The educators in these schools literally are beholden to the people of color in the communities to keep their schools open. Specific strategies to attract and maintain students included fostering interpersonal communications between faculty and caregivers, creating school-facilitated occasions for caregiver learning, and promoting various opportunities for community investment into the school.

Foremost among the barriers to attending SJA were the perpupil costs of running the schools serving families with limited means for paying tuition and the limitations of the schools' capacities to address the diverse needs of the pluralistic community (e.g., differentiation in instruction for students with diverse learning needs). As a result, SJA undertook multifarious efforts to expand the base of financial support through private donors and foundations as well as the base of human resource support through volunteers. This may have an effect of compelling the (White, privileged) educators to paradoxically recognize their role as one of service and dependence. Delpit (1988) asks, "Will Black teachers and parents continue to be silenced by the very forces that claim to 'give voice' to our children?" (p. 296). The evidence in this study suggests that in certain schools, the answer is no. Some schools, even where the majority of the teachers are racially and economically privileged, make concerted efforts to listen to the voices of the caregivers and community members, most of whom have been traditionally marginalized.

In another way, these spaces can be understood as rooted in values, not tactics. If the enrollment pressures drive these schools to expand their communities from a resource perspective, the religious values of the schools compelled this expansion as well. In a sense, the

Marriage and Family Review, Vol. 43, No. 3-4 (2008): pg. 308-337. DOI. This article is (C) Taylor \& Francis (Routledge) and permission has been granted for this version to appear in e-Publications@Marquette. Taylor \& Francis (Routledge) does not grant permission for this article to be further copied/distributed or hosted elsewhere without the express permission from Taylor \& Francis (Routledge). 
enrollment pressure could be considered the stick, compelling the educators to expand their practices of caregiver engagement, whereas the religious values could be considered the carrot, luring the educators to make these changes. The religious discourse in SJA grounds these educators in values that are asset-oriented rather than deficit-orientated. This context allows the principal of SMS to refer to the children as "priceless gifts from God" and the mission at SJA to espouse "nurtur[ing] the body, mind, and spirit of each child entrusted to our care."

This emphasis on valuing diverse forms of social and cultural capital is supported by previous research in the area of caregiver engagement. For instance, as Henderson and Mapp (2002) report in their summary of research on caregiver and community engagement, successful initiative are welcoming, collaborative, and serve diverse parent and community needs by "recogniz[ing], respect[ing], and address[ing] cultural and class differences" (p. 48). Viewing the data in this study through the lens of critical care theory foregrounds certain race-based and class-based dimensions these values. Specifically, the case of SJA suggests ways certain educational leaders are approaching communities of color through more nuanced lenses. The school's dependence on increasing participation from communities of color to support the schools, along with their espoused values, may reduce tendencies toward racism. SJA has not formalized this yet indicated many culturally responsive and asset-oriented approaches toward caregivers.

The data here imply that religious overtones serve to drown racial undertones, but a thorough examination of this is beyond the scope of this study. As Lipsitz (1998) suggests, Whites can ameliorate the inequities perpetuated by White privilege by adopting and acting on equity-oriented dispositions: "We do not choose our color, but we do choose our commitments" (p. viii). Educators in SJA showed commitments to working across racial and ethnic lines. In summary, the spaces valuing diverse forms of social and cultural capital are rooted in both values and strategies of the school.

\section{Alliances with Nontraditional Supports}

Marriage and Family Review, Vol. 43, No. 3-4 (2008): pg. 308-337. DOI. This article is @ Taylor \& Francis (Routledge) and permission has been granted for this version to appear in e-Publications@Marquette. Taylor \& Francis (Routledge) does not grant permission for this article to be further copied/distributed or hosted elsewhere without the express permission from Taylor \& Francis (Routledge). 
In addition to creating spaces that value diverse forms of social and cultural capital, SJA educators consistently cultivated innovative supports, both in the immediate and in the broader community, to more effectively serve their increasingly diverse students. For example, as part of the Stewardship Program, families were rewarded for active participation in a faith community of their choosing. Families demonstrated their participation by attending worship services and personal enrichment programs at these faith communities. Though a Catholic school, SJA supported the social networking of caregivers by encouraging them to attend a faith community of their choosing.

In addition, the educators gained support by way of grants of financial and in-kind support from numerous organizations in the broader community. The principal at SJA placed concerted efforts into building networks of support. From capital improvement projects (e.g., building a new playground area, painting the school, replacing windows) to tuition scholarship funds, businesses and local foundations were vital to the stability of SJA. The principal was also successful in finding personnel at reduced rates, including a special education consultant (supported by a local university), counselors (provided at a reduced rate by a local social service agency), and subsidized teachers (supported by a local teaching service corps organization).

Rather than being isolated from one another, these support structures tended to overlap and interconnect. They were typically created through a combination of innovation and desperation and strengthened the schools' capacities to value diverse forms of social and cultural capital. For instance, some of the support personnel (special education consultant and counselors) raised the capacity of the educators to recognize of the assets that the caregivers brought to the school and the uniqueness of each individual. Their efforts helped SJA create a teaching and learning community more responsive to the whole child.

Certain features of womanism are evident here. BeauboeufLafontant (2002) describes womanism as promoting "individual empowerment combined with collective action...[and] seek[ing] the

Marriage and Family Review, Vol. 43, No. 3-4 (2008): pg. 308-337. DOI. This article is (C) Taylor \& Francis (Routledge) and permission has been granted for this version to appear in e-Publications@Marquette. Taylor \& Francis (Routledge) does not grant permission for this article to be further copied/distributed or hosted elsewhere without the express permission from Taylor \& Francis (Routledge). 
liberation of all" (p. 72). Through this lens, caring is a tool of engaging the community in political activism. The risks that womanism entails to working for others are rooted in this connectivity (p. 81):

[C]ommitments to working for social justice rest on a concept of self that is part of rather than apart from other people....It is an intimacy with and not an aloofness from other people that motivates womanist educators to see personal fulfillment in working toward the common good.

By recognizing the ways that their students and families were marginalized and seeking to provide schooling that would be transformative and empowering to these individuals and families, educators in SJA show womanistic tendencies.

\section{Limitations to Spaces}

Although strong in many ways, these spaces of engagement are limited as well. The two limitations I discuss here are the lack of antiracism and the lack of creatively engaging caregivers outside the school setting.

One key limitation is the lack of an explicitly antiracist focus in the culture of the school. Despite the strengths of establishing strong personal relationships, educational leaders-who were primarily White women-failed to acknowledge the racial dynamics that are inherent in such a racially mismatched school setting. As illustrated in Table 1, those in positions of formal authority were predominantly White, whereas the majority of Black school personnel were not in leadership roles. Only one of the teacher research participants was Black. The secretary was Black and held considerable experiential authority, though more limited positional authority. Although two board members who were research participants were Black, these positions are of relatively limited authority, as the board serves solely as advisory. By contrast, virtually all the White research participants had strong roles in the school, at the administrative, teaching, or donor level.

The lack of explicitly acknowledging the dynamics of race indicated a level of "racial erasure" (McKenzie \& Scheurich, 2004),

Marriage and Family Review, Vol. 43, No. 3-4 (2008): pg. 308-337. DOI. This article is (C) Taylor \& Francis (Routledge) and permission has been granted for this version to appear in e-Publications@Marquette. Taylor \& Francis (Routledge) does not grant permission for this article to be further copied/distributed or hosted elsewhere without the express permission from Taylor \& Francis (Routledge). 
implying that issues of race were nonexistent or not important. By contrast, making a commitment to acknowledging White privilege and working toward antiracism would have strengthened these spaces. Professional development support and training to facilitate antiracism in schools were available to SJA through the central office. However, at the time of this research, the principal had not chosen to make use of this support.

In addition to failing to explicitly apply antiracist commitments, these spaces were limited by the failure of SJA educators to imaginatively extend these spaces outside the school. For instance, though educators in SJA were focused in engaging caregivers in innovative ways, they were not encouraged to conduct home visits or to conduct conferences in nonschool locations, such as community centers. By more creatively looking to discover the funds of knowledge that can become evident by interacting with families in nonschool settings (ERIC Digest, 1994; Moll \& Gonzalez, 2004), educators in SJA may have fostered stronger connections with caregivers. At the time of this research, no such efforts had been made.

In this discussion I argued that the educational leaders in SJA, beholden to the diverse student bodies for enrollment and grounded in a value system that espouses inclusion, created spaces that value diverse forms of social and cultural capital. However, these spaces have been limited in key ways. I now turn to the implications that emerge from this discussion.

\section{Conclusion}

Efforts to improve schools often focus on innovative approaches to caregiver and community engagement (Brooks, 2005; Christie, 2005; Haynes, 2005; Lopez, 2001; Lopez et al., 2001; Perez Carreon et al., 2005). Presenting a religious school that uses innovative and effective strategies to engage caregivers, this case study contributes to a deeper understanding of how critical care theory can build social justice practices in schools. This case indicates that educators may experience both a push and a pull toward engaging caregivers. This push and pull can occur at both the institutional and the individual level. At the school level, SJA was compelled to engage caregivers as a

Marriage and Family Review, Vol. 43, No. 3-4 (2008): pg. 308-337. DOI. This article is (C) Taylor \& Francis (Routledge) and permission has been granted for this version to appear in e-Publications@Marquette. Taylor \& Francis (Routledge) does not grant permission for this article to be further copied/distributed or hosted elsewhere without the express permission from Taylor \& Francis (Routledge). 
strategy of maintaining enrollment and was drawn to do so from its religious mission. At the individual level, the educators in the school were required to initiate consistent, focused, positive-oriented contacts with families, but they also expressed satisfaction in doing so.

The findings here indicate that many of the efforts to create spaces of engagement-from the personal attention of the principal and the strong relational networks of teachers with families-are more driven by dispositions and commitments more than by budgets. In other words, many of the significant features of SJA reported here did not depend on an influx of resources but rather on the attitudes of the educators. Further, this study suggests that the limitations of such efforts (for instance, the lack of an antiracist focus) are not necessarily due to the dearth of resources. Finally, the findings indicate ways in which nontraditional support structures can broaden the capacity of a school community to more effectively engage caregivers.

The case of SJA suggests that creating spaces valuing diverse forms of social and cultural capital is not inhibited by resources but by dispositions. The critical elements in this case-namely the intense personal relationship of the principal to caregivers, the proactive, positive, and focused attention from teachers, and the concerted efforts to reduce barriers to families-were all pursued without significant influxes of external resources. In particular, the systems to build these relationships, such as by the principal personally interviewing families, teachers initiating weekly positive contacts with families, and three-way conferencing.

The case of SJA can serve as a counter-narrative. Delgado (1989) explains that counter-narratives "open new windows into reality, showing us...possibilities for life other than the ones we live" (p. 2414). Counter-narratives accomplish this by presenting an alternative to the stock story, which, Delgado illustrates, "picks and chooses from among the available facts to present a picture of what happened: an account that justifies the world as it is" (p. 2421). The stories of critical care illustrated here are counter-narratives because they suggest alternatives to what Rolon-Dow (2005) described as "deficit-based, racialized caring narratives" (p. 104) that hamper

Marriage and Family Review, Vol. 43, No. 3-4 (2008): pg. 308-337. DOI. This article is @ Taylor \& Francis (Routledge) and permission has been granted for this version to appear in e-Publications@Marquette. Taylor \& Francis (Routledge) does not grant permission for this article to be further copied/distributed or hosted elsewhere without the express permission from Taylor \& Francis (Routledge). 
many school communities. Counter-narratives are tools to highlight a key barrier toward equity, which Delgado (1989) refers to as "the prevailing mindset by means of which members of the dominant group justify the world as it is, that is, with whites on top and browns and blacks at the bottom" (p. 2413). By contrast, the educators in SJA showed a willingness to challenge the inequities of the "world as it is." The research participants repeatedly reflected deep commitments to the dignity of each individual child and a respect for the caregivers in their lives. This was evident in the interview responses and supported by observations of the community and artifacts within it, such as the school mission.

A central limitation to this research is the focus on the perspectives of the educational leaders. This study fails to capture the perceptions of families and other community members. Including these perspectives would strengthen this research. This study also focuses on how the school pursues caregiver engagement. Moving toward students as the unit of analysis would reveal important insights into the effects of this engagement on social, emotional, and academic success. Although a certain level of school success is implied by the fact that parents are choosing to enroll their children as students in SJA, at no small personal and financial cost, a more focused examination of the elements of student outcomes would be valuable in future research.

A key implication of this study for future research is that diverse school settings may contain important lessons regarding caregiver and community engagement. Educational researchers would benefit from seeking counter-narratives from diverse settings. Mixed methods of ethnographies combined with survey data would contribute to a richer understanding of these contexts. Additionally, future research should examine links between caregiver and community engagement and multiple student outcomes, including academic, social, and personal measures.

An implication for educational leadership programs is the value of attending to case studies of schools seeking to systematically value diverse forms of social and cultural capital. Caregiver engagement is

Marriage and Family Review, Vol. 43, No. 3-4 (2008): pg. 308-337. DOI. This article is @ Taylor \& Francis (Routledge) and permission has been granted for this version to appear in e-Publications@Marquette. Taylor \& Francis (Routledge) does not grant permission for this article to be further copied/distributed or hosted elsewhere without the express permission from Taylor \& Francis (Routledge). 
related to how schools look outward to both serving and being served by their multiple constituencies. School leaders would learn from more practical examples and theoretical models to help them navigate these terrains, especially ones that explicitly address racial and class differences. Both preservice and practicing school leaders would benefit from critically analyzing such case studies that illustrate these complexities.

In conclusion, this research contributes to our evolving understanding of caregiver engagement by presenting a textured analysis of a case study as viewed through the critical care conceptual framework. The educational leaders in SJA create spaces for engaging caregivers and building community support through a combination of desperation and innovation, on one hand compelled by pressures to attract students to enroll and on the other hand drawn by espoused values affirming the dignity of all students. They forged innovative alliances that strengthen these spaces, and their stories are counternarratives to both deficit-oriented care models and to caricatures of private schools as bastions of elitism. These leaders provide important lessons for all educators committed to the social justice values of authentically engaging caregivers.

\section{Notes}

- Martin Scanlan, PhD, is Assistant Professor in the Department of Educational Policy and Leadership, School of Education, Marquette University, Milwaukee, WI 53201-1881.

- Address correspondence to Martin Scanlan, PhD, Assistant Professor, Educational Policy and Leadership, School of Education, Office: Schroeder Health Complex, 194, Marquette University, P.O. Box 1881, Milwaukee, WI 53201-1881. Telephone: 414-288-4434; Fax: 414-2883945; E-mail: martin.scanlan@marquette.edu

\section{References}

Abrams, L., \& Gibbs, J. T. (2002). Disrupting the logic of home-school relations: Parent involvement strategies and practices of inclusion and exclusion. Urban Education, 37, 384-398.

Alt, M. N., \& Peter, K. (2002). Private schools: A brief portrait. Washington, DC: National Center for Education Statistics.

Marriage and Family Review, Vol. 43, No. 3-4 (2008): pg. 308-337. DOI. This article is @ Taylor \& Francis (Routledge) and permission has been granted for this version to appear in e-Publications@Marquette. Taylor \& Francis (Routledge) does not grant permission for this article to be further copied/distributed or hosted elsewhere without the express permission from Taylor \& Francis (Routledge). 
NOT THE PUBLISHED VERSION; this is the author's final, peer-reviewed manuscript. The published version may be accessed by following the link in the citation at the bottom of the page.

Anderson, G. (1998). Toward authentic participation: Deconstructing the discourses of participatory reforms in education. American Educational Research Journal, 35, 571-603.

Bauer, A., \& Brown, G. D. M. (2001). Adolescents and inclusion: Transforming secondary schools. Baltimore: Paul H. Brookes Publishing Co.

Beauboeuf-Lafontant, T. (2002). A womanist experience of caring: Understanding the pedagogy of exemplary black women teachers. Urban Review, 34, 71-86.

Beck, L. (1994). Reclaiming educational administration as a caring profession. New York: Teachers College Press.

Berger, E. H. (2000). Parents as partners in education: Families and schools working together. Upper Saddle River, NJ: Merill.

Brooks, S. (2005). Increasing minority parent involvement by changing the parameters from teacher-centered to parent-centered models. Paper presented at the National Conference of the University Council for Educational Administration, Nashville, Tennessee, November 10-13, 2005.

Carlisle, L. R., Jackson, B. W., \& George, A. (2006). Principles of social justice education: The social justice education in schools project. Equity and Excellence in Education, 39, 55-64.

Carspecken, P. F. (1996). Critical ethnography in educational research. New York: Routledge.

Charles A. Dana Center. (1999). Hope for urban education: A study of nine high-performing, high-poverty, urban elementary schools. Washington, DC: U.S. Department of Education, Planning, and Evaluation Service.

Christie, K. (2005). Changing the nature of parent involvement. Phi Delta Kappan, 86, 645-646.

Coleman, J. (1991). A federal report on parental involvement in education. The Education Digest, 57, 3.

Delgado, R. (1989). Storytelling for oppositionists and others: A plea for narrative. Michigan Law Review, 87, 2411-2441.

Delpit, L. (1988). "The silenced dialogue: Power and pedagogy in educating other people's children". Harvard Educational Review, 58, 280-298.

Dwyer, D., \& Hecht, J. (1992). Minimal parental involvement. School Community Journal, 2, 53-66.

Eccles, J. S., \& Harold, R. D. (1996). Family involvement in children's and adolescents' schooling. In A. Booth \& J. F. Dunn (Eds.), Family school links: How do they affect educational outcomes?, pp. 3-33. Mahwah, N]: Lawrence Erlbaum.

Epstein, J. (1986). Parents' reactions to teacher practices of parent involvement. The Elementary School Journal, 86, 277-294.

Marriage and Family Review, Vol. 43, No. 3-4 (2008): pg. 308-337. DOI. This article is (C) Taylor \& Francis (Routledge) and permission has been granted for this version to appear in e-Publications@Marquette. Taylor \& Francis (Routledge) does not grant permission for this article to be further copied/distributed or hosted elsewhere without the express permission from Taylor \& Francis (Routledge). 
Epstein, J. (1990). School and family connections: Theory, research, and implications for integrating sociologies of education and family. Marriage \& Family Review, 15, 99-126.

Epstein, J. (1993). Power in partnership. Teachers College Record, 94, 710717.

Epstein, J. (1997). Six types of school-family-community involvement. Harvard Education Letter (September/October). Retrieved May 2, 2008 from http://www.edletter.org/past/issues/1997-so/sixtypes.shtml.

Epstein, J., \& Salinas, K. C. (2004). Partnering with families and communities. Educational Leadership, 61, 12-18.

ERIC Digest. (1994). Funds of knowledge: Learning from language minority households. ERICRIEO, 19940201.

Fan, X., \& Chen, M. (2001). Parental involvement and students' academic achievement: A meta-analysis. Educational Psychology Review, 13, 122.

Fine, M. (1993). [Ap]parent involvement: Reflections on parents, power, and urban public schools. Teachers College Record, 94, 682-710.

Freeman, J. (1975). Three-way conferencing. Teacher, 93, 40-42.

Gutman, L. M., \& McLoyd, V. (2000). Parents' management of their children's education within the home, at school, and in the community: An examination of African-American families living in poverty. The Urban Review, 32, 1-24.

Hanafin, J., \& Lynch, A. (2002). Peripheral voices: Parental involvement, social class, and educational disadvantage. British Journal of Sociology of Education, 23, 35-49.

Haynes, K. (2005). The alchemy of hardship: Transmuting Latino's parent capital. Paper presented at the National Conference of the University Council for Educational Administration, Nashville, Tennessee.

Henderson, A., \& Mapp, K. L. (2002). A new wave of evidence: The impact of school, family, and community on student achievement. Austin, TX: Southwest Educational Development Laboratory.

Hoge, D., Smit, E., \& Crist, J. (1997). Four family process factors predicting academic achievement for sixth and seventh grade. Educational Research Quarterly, 21, 27-42.

Jeynes, W. (2005a). A meta-analysis of the relation of parental involvement to urban elementary school student academic achievement. Urban Education, 40, 237-269.

Jeynes, W. (2005b). Effects of parental involvement and family structure on the academic achievement of adolescents. Marriage \& Family Review, $37,99-116$.

Marriage and Family Review, Vol. 43, No. 3-4 (2008): pg. 308-337. DOI. This article is (C) Taylor \& Francis (Routledge) and permission has been granted for this version to appear in e-Publications@Marquette. Taylor \& Francis (Routledge) does not grant permission for this article to be further copied/distributed or hosted elsewhere without the express permission from Taylor \& Francis (Routledge). 
NOT THE PUBLISHED VERSION; this is the author's final, peer-reviewed manuscript. The published version may be accessed by following the link in the citation at the bottom of the page.

Lareau, A., \& Horvat, E. M. (1999). Moments of social inclusion and exclusion: Race, class, and cultural capital in family-school relationships. Sociology of Education, 72, 37-53.

Lareau, A., \& Shumar, W. (1996). The problem of individualism in familyschool policies. Sociology of Education, 69, 24-39.

Lincoln, Y., \& Guba, E. (1985). Naturalistic inquiry. Beverly Hills, CA: Sage Publications.

Lipsitz, G. (1998). The possessive investment in whiteness: How white people profit from identity politics. Philadelphia: Temple University Press.

Lopez, G. R. (2001). The value of hard work: Lessons on parent involvement from an (im)migrant household. Harvard Educational Review, 71, 416437.

Lopez, G. R., Scribner, J. D., \& Mahitivanichcha, K. (2001). Redefining parental involvement: Lessons from high-performing migrant-impacted schools. American Educational Research Journal, 38, 253-288.

Mandara, J. (2006). The impact of family functioning on African American males' academic achievement: A review and clarification of empirical literature. Teachers College Record, 108, 206-223.

Maxwell, J. (1998). Designing a qualitative study. In L. Bickman \& D. Rog (Eds.), Handbook of applied social research methods (pp. 69-100). Thousand Oaks, CA: Sage Publications.

McKenzie, K. B., \& Scheurich, J. J. (2004). Equity traps: A useful construct for preparing principals to lead schools that are successful with racially diverse students. Educational Administration Quarterly, 40, 601-631.

Moll, L., \& Gonzalez, N. (2004). Engaging life: A funds-of-knowledge approach to multicultural education. In J. A. Banks \& C. A. M. Banks (Eds.), Handbook of research on multicultural education (pp. 699715). San Francisco: John Wiley \& Sons.

Noddings, N. (2005a). Identifying and responding to needs in education. Cambridge Journal of Education, 35, 147-159.

Noddings, N. (2005b). The challenge to care in schools: An alternative approach to education (2nd ed.). New York: Teachers College Press.

Osterman, K. (2000). Students' need for belonging in the school community. Review of Educational Research, 70, 323-367.

Patton, M. Q. (1990). Qualitative evaluation and research methods. Newbury Park, CA: Sage Publications.

Perez Carreon, G., Drake, C., \& Calabrese Barton, A. (2005). The importance of presence: Immigrant parents' school engagement experiences. American Educational Research Journal, 42, 465-498.

Rodgers, K. B., \& Rose, H. (2001). Personal, family, and school factors related to adolescent academic performance: A comparison by family structure. Marriage \& Family Review, 33, 47-52.

Marriage and Family Review, Vol. 43, No. 3-4 (2008): pg. 308-337. DOI. This article is @ Taylor \& Francis (Routledge) and permission has been granted for this version to appear in e-Publications@Marquette. Taylor \& Francis (Routledge) does not grant permission for this article to be further copied/distributed or hosted elsewhere without the express permission from Taylor \& Francis (Routledge). 
NOT THE PUBLISHED VERSION; this is the author's final, peer-reviewed manuscript. The published version may be accessed by following the link in the citation at the bottom of the page.

Rolon-Dow, R. (2005). Critical care: A color(full) analysis of care narratives in the schooling experiences of Puerto Rican girls. American Educational Research Journal, 42, 77-111.

Scanlan, M. (2006). Problematizing the pursuit of social justice education. UCEA Review, XLX (3), 6-8.

Stake, R. (1985). Case study. In J. Nisbet, J. Megarry, \& S. Nisbet (Eds.), World yearbook of education, 1985: Research, policy, and practice. New York: Nichols Publishing Company.

Stake, R. (1995). The art of case study research. Thousand Oaks, CA: Sage Publications.

Stolz, H., Barber, B., Olsen, J., Erickson, L., Bradford, K., Maughan, S., \& Ward, D. (2004). Family and school socialization and adolescent academic achievement: A cross-national dominance analysis of achievement predictors. Marriage \& Family Review, 36, 7-33.

Strauss, A., \& Corbin, J. (1990). Basics of qualitative research: Grounded theory procedures and techniques. Newbury Park, CA: Sage Publications.

Valencia, R. (Ed.). (1997). The evolution of deficit thinking: Educational thought and practice. Washington, DC: Falmer Press.

Valenzuela, A. (1999). Subtractive schooling: U.S.-Mexican youth and the politics of caring. Albany, NY: State University of New York Press.

Yin, R. (2003). Case study research: Design and methods (3rd ed.). Thousand Oaks, CA: Sage Publications.

Ysseldyke, J., \& Algozzine, B. (2006). Working with families and community agencies to support students with special needs. Thousand Oaks, CA: Corwin Press.

Marriage and Family Review, Vol. 43, No. 3-4 (2008): pg. 308-337. DOI. This article is @ Taylor \& Francis (Routledge) and permission has been granted for this version to appear in e-Publications@Marquette. Taylor \& Francis (Routledge) does not grant permission for this article to be further copied/distributed or hosted elsewhere without the express permission from Taylor \& Francis (Routledge). 
NOT THE PUBLISHED VERSION; this is the author's final, peer-reviewed manuscript. The published version may be accessed by following the link in the citation at the bottom of the page.

\section{Appendix}

\section{Table 1}

\section{Race of Research Participants at SJA}

\begin{tabular}{|c|c|}
\hline White & Black \\
\hline \multicolumn{2}{|l|}{ Administrator: } \\
\hline \multicolumn{2}{|l|}{$\begin{array}{l}\text { Ms. Green, principal (15 years, plus } 15 \\
\text { more as a teacjer }\end{array}$} \\
\hline Teachers: & Teacher: \\
\hline $\begin{array}{l}\text { Ms. Abrams: middle school teacher ( } 22 \\
\text { years) }\end{array}$ & $\begin{array}{l}\text { Ms. Abrams: middle school teacher ( } 22 \\
\text { years) }\end{array}$ \\
\hline \multicolumn{2}{|l|}{$\begin{array}{l}\text { Ms. Frank: teacher and librarian (5 } \\
\text { years) }\end{array}$} \\
\hline \multicolumn{2}{|l|}{ Ms. Grady: primary teacher (1 year) } \\
\hline \multicolumn{2}{|l|}{ Ms. Morgan: primary teacher (2 years) } \\
\hline \multicolumn{2}{|l|}{$\begin{array}{l}\text { Ms. Sterling: primary teacher in primary } \\
\text { (4 years) }\end{array}$} \\
\hline Other participants: & Other participants: \\
\hline \multirow[t]{6}{*}{$\begin{array}{l}\text { Mrs. Baker: major donor and volunteer } \\
\text { for } 5 \text { years }\end{array}$} & $\begin{array}{l}\text { Mrs. Cross: board member and volunteer } \\
\text { (12 years) }\end{array}$ \\
\hline & $\begin{array}{l}\text { Ms. Mayes: volunteer and classroom aide } \\
\text { (15 years) }\end{array}$ \\
\hline & Mrs. McNess: volunteer (32 years) \\
\hline & Ms. Wallace: secretary (17 years) \\
\hline & $\begin{array}{l}\text { Ms. Wells: board member and volunteer } \\
\text { ( } 20 \text { years) }\end{array}$ \\
\hline & Ms. Wellstone: part-time aide (10 years) \\
\hline
\end{tabular}

Marriage and Family Review, Vol. 43, No. 3-4 (2008): pg. 308-337. DOI. This article is (C) Taylor \& Francis (Routledge) and permission has been granted for this version to appear in e-Publications@Marquette. Taylor \& Francis (Routledge) does not grant permission for this article to be further copied/distributed or hosted elsewhere without the express permission from Taylor \& Francis (Routledge). 
NOT THE PUBLISHED VERSION; this is the author's final, peer-reviewed manuscript. The published version may be accessed by following the link in the citation at the bottom of the page.

\section{Figure 1 \\ Overview of SJA}

Overview of SJA

\begin{tabular}{|c|c|}
\hline $\begin{array}{l}\text { School Context } \\
\text { History: Formed in } 1990, \text { serving } \\
\text { students from pre-school }-8^{\text {th }} \text { grade } \\
\text { Students: } 260 \text { students } \\
\text { Tuition: } \$ 2680 \text { for one student } \\
\qquad 3743 \text { for two students } \\
\quad \$ 4422 \text { for three students } \\
\text { Affiliation: Regional Diocesan School }\end{array}$ & $\begin{array}{l}\text { Traditionally Marginalized Students } \\
\text { Students in poverty: } 94 \% \\
\text { Racial / Ethnic Diversity: } 100 \% \text { (African American) } \\
\text { Linguistic Diversity: } 0 \\
\text { Students with special needs: } 12 \% \text { (estimate) }\end{array}$ \\
\hline SJA & $\begin{array}{l}\text { 1Administration Participant } \\
\text { Ms. Green-principal ( } 15 \text { years); } \\
\text { employee of school ( } 30 \text { years). }\end{array}$ \\
\hline $\begin{array}{l}7 \text { Other Participants } \\
\text { Mrs. Baker: Major donor, volunteer ( } 5 \text { years) } \\
\text { Mrs. Coss: Board member and volunteer ( } 12 \text { years) } \\
\text { Ms. Mayes: volunteer and classroom aide ( } 15 \\
\text { years) } \\
\text { Mrs. McNess: volunteer ( } 32 \text { years) } \\
\text { Ms. Wallace: Secretary (17 years) } \\
\text { Ms. Wells: Board member and volunteer ( } 20 \text { years) } \\
\text { Ms. Wellstone: Part-time aide (10 years) }\end{array}$ & $\begin{array}{l}\text { 6 Faculty Participants } \\
\text { Ms. Abrams: Middle School Teacher ( } 22 \\
\text { years) } \\
\text { Ms. Frank: Teacher / Librarian ( } 5 \text { years) } \\
\text { Ms. Grady: Primary Teacher ( } 1 \text { year) } \\
\text { Ms. Harris: Intermediate Teacher ( } 17 \text { years) } \\
\text { Ms. Morgan: Primary Teacher ( } 2 \text { years) } \\
\text { Ms. Sterling: Primary Teacher in primary ( } 4 \\
\text { years) }\end{array}$ \\
\hline
\end{tabular}

Marriage and Family Review, Vol. 43, No. 3-4 (2008): pg. 308-337. DOI. This article is (C) Taylor \& Francis (Routledge) and permission has been granted for this version to appear in e-Publications@Marquette. Taylor \& Francis (Routledge) does not grant permission for this article to be further copied/distributed or hosted elsewhere without the express permission from Taylor \& Francis (Routledge). 